\title{
Would Engineers Need Non-technical Skills or Non-technical Competences or Both?

\author{
http://dx.doi.org/10.3991/ijep.v3i2.2405
}

\author{
V. Parts, M. Teichmann and T. Rüütmann \\ Tallinn University of Technology, Tallinn, Estonia
}

\begin{abstract}
Two main competence approaches are under the discussion. There is evidence that graduates do not fully perceive and/or underestimate the influence of non-technical competences on their employability. An understanding of the necessity of non-technical competences develops after a graduate has already been hired and is working at that job.
\end{abstract}

Index Terms-Competency, competence, engineering nontechnical competences, employability, the gap between engineers' required and real competences.

\section{INTRODUCTION}

The starting point for this paper is the need to provide a clear and coherent definition of professional engineers' non-technical skills or competences. Unfortunately, this is not as straightforward as it may seem. Despite the terms "non-technical competences", "soft skills", and "nontechnical skills" being used in articles published in recent years, the scientific community has still not reached an agreement on the definition and the exact content and meaning of non-technical competences. On the one hand, employers have reached the conclusion that in addition to excellent technical competence, engineering also requires some kind of successful social behaviours [1], [2], [3], [4], [5], [6]. On the other hand, researchers have largely reached a consensus on the same matter [7], [8], [9], [10], [11], [12], [13], [14]. In literature there is empirical evidence for an existing link between non-technical competences and employability [15], [16], [17], [18].

No agreement has been reached regarding what exactly the non-technical skills or competences are in their content. Ongoing debate shows clearly that different researchers understand this issue differently and are offering different "packages" of engineers' non-technical skills [19], [20], [21]. Still there is no consensus about whether it should be defined in terms of skills or competences or both. Moreover, we have to look to history for a better understanding of the larger term "competence", as there are two different and competing approaches in scientific liaterature. This lack of coherence has lead to a degree of fragmentation in engineering education literature and may explain why it is difficult for researchers and educators to understand each other.

This interest in competences has also reached the field of higher education. There are increasing calls for competence-oriented engineering education, including in academic contexts [22], [23] and this trend is continuing.

\section{THEORETICAL FRAMEWORK}

\section{A. First Approach: Competency}

The term "competence" first appeared in an article authored by Craig C. Lundberg in 1970 [24] and it is widely used in personnel and human resource literature. Current interest dates back to Hamel \& Prahalad [25], who spoke about a company's "core competences" in the context of strategic management. "Core competence" is seen as a distinguishing feature in which an organisation excels, a source of competitive advantage, and a base for success.

The term competence was known in Europe as a "learned capacity to perform", but not widely used beyond occupational education. Competences have meanwhile spread to education and the trend is still going on. In the USA, competency is mainly defined as any characteristics relating to superior performance. Spencer and Spencer [26] created an Iceberg model (Figure 1) of competency and have defined competency as "an underlying characteristic of an individual that is causally related with criterionreferenced effective and/or superior performance in a job or situation".

In this approach competency equals the basic features of a person that are associated with superior performance in a situation. Five features of competency were identified, namely motives, traits, self-perception, knowledge, and skills. Motives are the forces that a person consistently thinks about. Motives lead behaviors towards specific activities or goals. A trait is an element of personality that is relatively stable throughout the lifespan and across contexts. Self-perception is a personal attitude. Knowl-

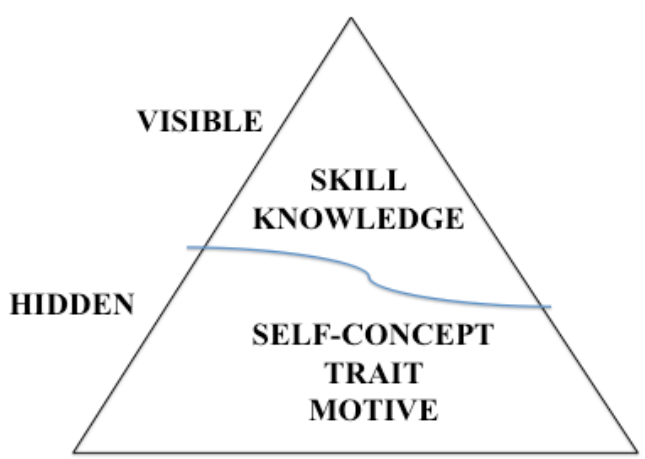

Figure 1. Iceberg Model (modified by L.M. Spencer, \& S.M. Spencer, 1993) 
edge includes information that a person has in his own range. Finally, skill is the ability to perform a specific mental or physical task. Knowledge and skills are related to obvious and superficial features while self-perception and motivation characteristics relate to personality characteristics and the deep or hidden features of individuals. From a theoretical point of view, work and organizational psychologists do not fully agree on a general definition for and conceptualization of competency [27], [28], [29].

\section{B. Second Approach: Competence}

The second approach is widely used in the EU, and in it competence is defined as a learned capacity to perform. Roe [30] has defined competence as "a learned capacity of an individual to adequately perform a task, duty or role". In an Architectural model offered by Roe [28] the competences should be differentiated into knowledge, skill and attitude, and described through abilities, personality traits, and other characteristics (Figure 2).

In mainstream psychology literature, skill is understood as the capacity for carrying out complex, well-organized patterns of behavior smoothly and adaptively so as to achieve some end or goal. Although this term was originally used largely with respect to motor activity, it is now commonly used when talking about verbal and social skills. A skill does not develop on its own from nothing skill is based on knowledge, and skills develop through the practical use and application of prior knowledge. Professional attitudes are understood as a person's readiness or willingness to act in accordance with his personal values. A person's abilities are his capacity to acquire necessary knowledge and skills. Personality traits are, for example, neuroticism, agreeableness, rigidity, impulsiveness, etc. Other characteristics are, for example, appropriate education, successful school history, average grade in math and physics, apparent interest in IT, etc.

\section{Engineering non-technical competences}

From a theoretical perspective and for several reasons we prefer to follow the Architectural model of competences offered by Roe [31]. First, this theoretical model is based on well-defined work and organizational psychology theories and concepts that complement one another; in addition, it fits with existing theories of learning and activity. Second, this theoretical framework is transferable to different occupations. Third, the model provides the opportunity to define competences as a learned capacity to perform, i.e. fills in the notion of experience. One can view an engineer's competences as a set of behaviors that enables him to do a job properly. In this way, competences are regarded as a result (output) preceded by something. Fourth, the model provides an opportunity to understand the interrelation between the input and output of engineering competences. As in any other profession, in engineering there should be some combination of an input (knowledge, skills, and attitudes) and an output - competences. The development of competences is influenced by abilities, personality traits and other characteristics (and hence is different from these).

Shifting our focus back to the engineers' non-technical competences, there is a need to develop an explanatory knowledge of human behavior and its context in work, organization, and personal as well as inter-personal fields, with skills developing through the process of using knowledge in every-day work practice. Professional

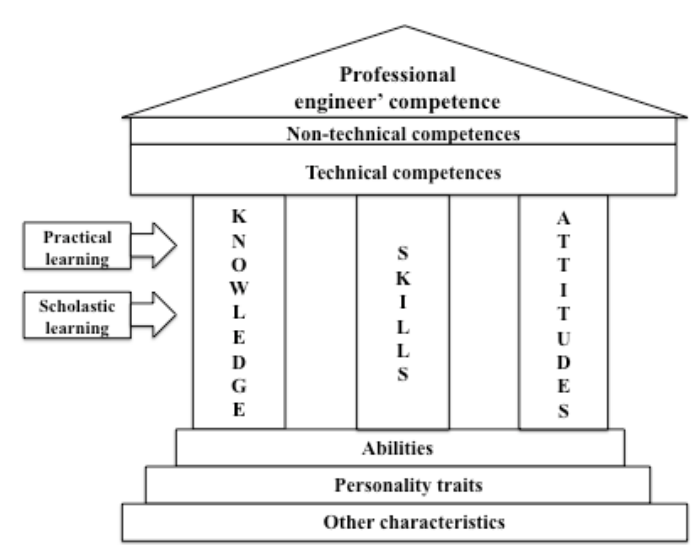

Figure 2. Architectural Model of Engineers' Competences (modified by D. Bartram and R.A. Roe, 2005)

attitudes provide a general frame for a person's decisions and actions. Thus competences are based on all three elements. Based on the described understanding, nontechnical engineering competences can be defined as "a specific range of non-technical knowledge, skills, and attitudes/value system needed to adequately perform the professional work and professional roles of engineer".

\section{RESEARCH}

\section{A. Research method}

Tallinn University of Technology (TUT) conducted a study of graduated (2008 alumni) students at the end of 2009 , e.g. one and a half years after their graduation. The survey used for the study had 20 sections and contained 152 questions that the respondent had to answer. In addition to these, the survey also included socio-demographic information (age, sex, language spoken at home, gross salary, current sources of income, work experience) and optional questions about the department, graduating level, and major of the subject's studies. The survey organizers sent out 1473 invitations to fill out the web-based survey. Due to incomplete address information, 51 graduates were left out of the survey. A total of 534 people $(51 \%$ female, $49 \%$ male) filled the survey, a rate of $36 \%$. The survey was compiled and the process carried out by the TUT Career and Counseling Office. Analysis was performed in the TUT Department of Industrial Psychology.

The questionnaire included a special block of questions regarding engineers' need for competences. Competences that were evaluated were:

- Knowledge that expands one's worldview;

- Computer skills;

- Learning skills;

- Foreign languages;

- Analysis and synthesis/critical thinking;

- Leadership;

- Social skills (for ex. teamwork, negotiations, selfassertion);

- Self-expression and presentation skills;

- Professional knowledge;

- Practical professional skills.

Two of the named competences were technical competences (professional knowledge and practical professional 
PAPER

WOUld ENGINEERS NEED NON-TECHNICAL SKILlS OR NON-TECHNICAL COMPETENCES OR BOTH?

skills); knowing a foreign language relevant to the profession and computer skills on the level required by the field are general competences for the engineering profession, and analysis and synthesis/critical thinking (characteristic of many different fields), and five were non-technical competences. The graduates evaluated separately to what degree they felt their knowledge and skills (meaning the preparation they had in university) helped in finding a job.

For responses the Likert-type forced choice 5-point scale was chosen as the most widely used scale in survey research. A Likert item is simply a statement that the respondent is asked to evaluate according to any kind of subjective or objective criteria; generally the level of agreement or disagreement is measured. Response scale was:

- Strongly disagree;

- Disagree;

- Do not know;

- Agree;

- Strongly agree.

Unfortunately the graduates only evaluated the given competences on the Likert 5-point scale and did not have an opportunity to give free responses. Therefore if some competence was missing from the list, it was not possible for the respondents to evaluate that competence.

\section{B. Employability and Work Satisfaction}

The proportion of students who found work, i.e. the employment rate, was high $-81 \% ; 2 \%$ were unemployed; $22 \%$ were continuing their studies either as their main activity or in addition to working. $93 \%$ of graduates were happy with their choice of field and $89 \%$ felt that they were getting along well at their current jobs. $85 \%$ of the graduates were working in the same field they studied; of these $45 \%$ were mid-level specialists or technicians, $22 \%$ were working as top specialists, and $12 \%$ in leadership positions.

Satisfaction with one's work and competitiveness on the labor market (employability) were measured on the basis of two statements, "I am satisfied with my work" and "I feel I am competitive on the labor market". $85 \%$ of respondents were satisfied with their work, $10 \%$ were not satisfied, and $5 \%$ did not know; $89 \%$ of the graduates felt they were competitive on the labor market (employability), $8 \%$ did not feel competitive, and 3\% did not know.

TUT's earlier graduate studies on the dynamics of employability, work satisfaction, and working in one's field of specialization suggest that employability and working in one's specialty have decreased somewhat compared to the last study from 2006 (Table 1).

TABLE I.

DYNAMICS OF EMPLOYABILITY AND WORK SATISFACTION

$\begin{array}{cccc}\begin{array}{c}\text { Graduation } \\ \text { (year) }\end{array} & \begin{array}{c}\text { Employability } \\ \text { (\%) }\end{array} & \begin{array}{c}\text { Work satisfac- } \\ \text { tion (\%) }\end{array} & \begin{array}{c}\text { Work in } \\ \text { specialty } \\ (\%)\end{array} \\ 2000 & 86 & 76 & 93 \\ 2001 & 87 & 71 & 92 \\ 2002 & 97 & 76 & 93 \\ 2004 & 95 & 82 & 92 \\ 2005 & 86 & 81 & 89 \\ 2006 & 92 & 85 & 94 \\ 2008 & 89 & 85 & 89\end{array}$

Employability ranged from $86 \%$ (in 2000) to $97 \%$ (in 2002). Work in one's specialty is another indicator for evaluating the acquired higher education. If there are many graduates who do not find a job in their specialty, there could be an "overproduction" of specialists, a negative economic trend, or graduates do not have adequate competences to get a job. Through the years the percentage of graduates who get a professional job has ranged between $89 \%$ and $94 \%$. The graduates' work satisfaction has a tendency to increase year by year. In $200076 \%$ graduates were satisfied with their every-day work, and in 2006 and 2008 there was 9\% increase in graduates who were satisfied with their everyday work.

\section{Employability and Non-Technical Competences}

The surveyed graduates $(\mathrm{N}=425)$ evaluated how the competences they acquired in university helped them in finding a job after their graduation (see Figure 3.)

The factors that were evaluated as being most important in getting a job were computer skills (91\% agreed, 7\% disagreed) and learning skills (89\% agreed, 9\% disagreed). These were followed by professional knowledge (87\% agreed, 11\% disagreed), professional practical skills (74\% agreed, $24 \%$ disagreed), and competences in analysis, synthesis/critical thinking (87\% agreed, $9 \%$ disagreed).

Such typical non-technical competences as social competences (agreed $80 \%$, disagreed 16\%), self-expression, presentation skills (agreed 75\%, disagreed 20\%), and foreign language (general competence; agreed $81 \%$, disagreed 18\%) were also evaluated highly as competences positively affecting employment.

The main disagreement was with respect to the two non-technical competences, namely the general understanding of the world and leadership competences. More than one-quarter of the respondents did not believe $(27 \%$ disagreed, $68 \%$ agreed) that their general understanding of the world had a positive influence on their employment. $52 \%$ of graduates did not feel that leadership competences were an important factor in their becoming employed and less than half of respondents (41\% agreed) felt that leadership competences affected the landing of a job positively.

Disagreement was also relatively high regarding the necessity of such competences as professional practical skills (24\% disagreed), self-expression, presentation skills (20\% disagreed), foreign language (16\% disagreed).

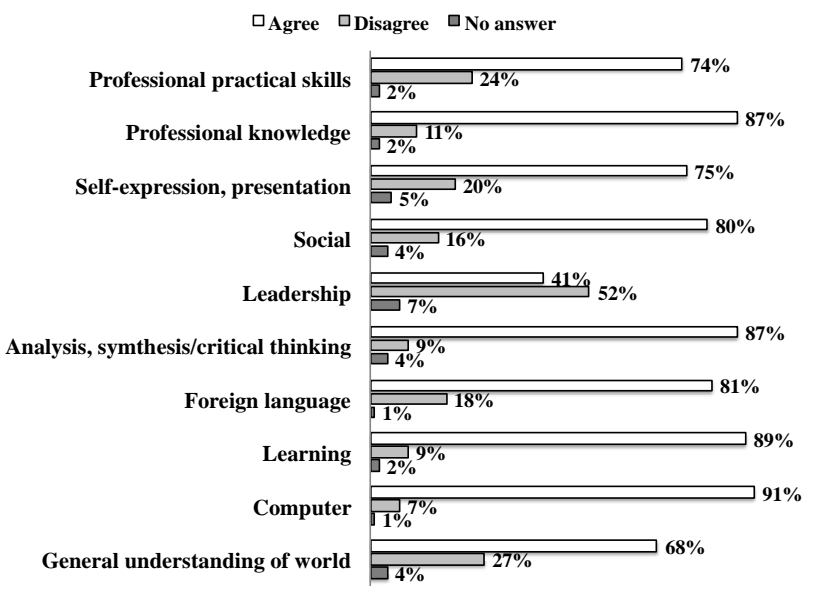

Figure 3. Employability - Technical and Non-Technical Competences that Influenced Employment 
PAPER

Would ENGINEERs NEED NON-TECHNICAL SKILls OR NON-TECHNICAL COMPETENCES OR BOTH?

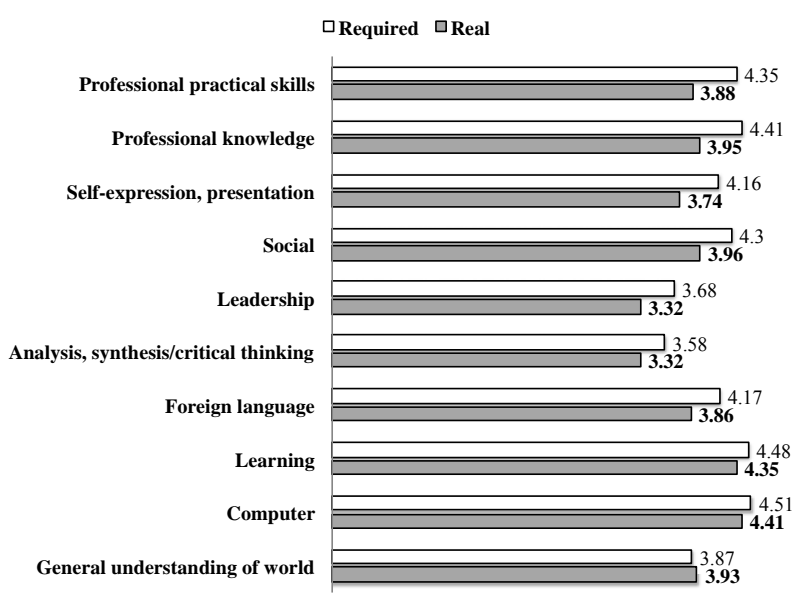

Figure 4. Graduates Comparing Technical and Non-Technical Competences Required for Their Jobs with Their Own Competence Level

Surprisingly, $11 \%$ of respondents disagreed with the necessity of professional knowledge as a positive factor in their employment.

\section{The Gap Between Required and Real Competences}

TUT graduates $(\mathrm{N}=425)$ evaluated the level of competences recommended for their current position and compared that with the level of their existing competences.

A gap did exist between the recommended level of competences and the actual level of their competences on the 5-point scale the difference was around 0.5 (Figure 4).The largest negative gap was found in the comparison of estimated real professional knowledge and real practical professional skills with required professional knowledge and required professional practical skills (respectively the gaps were -0.46 and -0.47 ).

A negative gap was found between real and required competence levels in such non-technical competencies like self-expression, presentation skills (gap is -0.42), social skills (gap is -0.34), leadership competences (gap is -0.36), analysis, synthesis and critical thinking (gap is 0.26 ), and foreign language (gap is -0.31).

\section{DISCUSSION}

The university graduates evaluated their level of competence as equal to the recommended level for their job in general understanding of the world (gap is positive, +0.06 ). For all the rest of the competence assessments there is a negative gap between real and required competences at the current job. The smallest negative gap was found in computer competences (gap is -0.1).

The terminological confusion concerning the definitions and concepts of competence often reflects the conflation of distinct concepts and inconsistent usage of terms. The few attempts to establish coherent terminology have had little impact to date. Boak [31] argued that competency in the American sense is exactly the same as competence as it used in the UK occupational standards. We agree with Burgoyne [32] who similarly distinguishes "being competent" (meeting the job demands) from "having competencies" (possessing the necessary attributes to perform competently), i.e. to adequately perform professional work and different professional roles.
We found that the term "soft skills" is used in different disciplines and in content it emphasizes the bipolar position, such as hard skills (mainly understood as technical skills) vs. soft skills (mainly understood as social skills); as well as technical vs. non-technical skills in engineering education.

As noted, we analyzed the results of the TUT graduates study (2008 alumni) with a focus on engineers' professional competences. A relatively high employment rate, employability, and satisfaction with one's work were found among the graduates.

A high level of consensus was found among graduates that computer and learning skills were those that had the greatest importance in getting a job. However, these two competences were also the ones that had the smallest gap between the real and required competences at work. In other words, these two competences were already well developed during studies at the university and increased the employability of graduates.

The two main technical competences, respectively professional knowledge and professional practical skills, were evaluated as the second priority for employability. In evaluating their real and required technical competences, in the current study the gap was greatest among the aforementioned set of competences.

Regarding other competences, the one rated as having the highest impact on graduates' employability was the analysis, synthesis and critical thinking as general competence followed immediately by technical competences. The gap between the real and required levels of analysis, synthesis and critical thinking competences was comparably smaller than the gap in the case of technical competences.

Such non-technical competences as social competences, self-expression and presentation skills, and foreign language (general competence) were widely evaluated as being necessary in the context of employability, but quite a large negative gap was found between the real and required competence level.

The most intriguing finding was that in the evaluation of leadership competences, there exists a tendency to underestimate the importance of leadership competences for employability. Moreover, a negative gap was found in the comparison of the estimated real and required leadership competences.

The finding that graduates' general understanding of the world does not have so much influence on their employability is not easily interpretable. We assume that as graduates evaluate their general understanding of world as something that they had already, this came out as the single positive gap between real and required competence levels in study. There was a quite similar finding in a study of Estonian universities graduates (2009 alumni) that was carried out in 14 universities, including TUT [33].

Of course, there exists a possibility that employers do not consider non-technical competences during the recruiting process, but if you are already employed nontechnical competences are required for being an employee. Therefore, when starting their professional careers, graduates discover that the level of non-technical competences required by the job and what they actually have is, unfortunately, different. 


\section{CONCLUSIONS}

Based on the analysis of existing literature and the current research findings, we reached four main conclusions.

First of all, both the theoretical perspective and evidence-based competence models sorely need for some agreements to be reached regarding terms, definitions, and theoretically valid concepts as well in regarding engineers' competences. For a deeper understanding of engineers' technical and non-technical competences, interdisciplinary cooperation and collaboration with researchers, educators, practitioners, employers, educational policy makers, professional bodies, and other stakeholders is needed.

Second, graduates do not fully perceive and/or they underestimate the influence of non-technical competences on their employability. An understanding of the necessity of non-technical competences develops after a graduate has already been hired and is working at that job.

Third, the learning and the analysis, synthesis and critical thinking competences were most highly evaluated competences in the context of employability. In such competences as social ones (for ex. teamwork, negotiations, self-assertion), self-expression, presentation, and foreign language, a considerable gap was found between real competences and required competences for a job.

Fourth, we found that there exists a tendency to underestimate the importance of leadership competences for employability. A negative gap was found in comparing one's estimated real leadership competence and the leadership competence required for job leadership. Taking into consideration that a third of the TUT graduates surveyed were working in a leadership position or as a top specialist just 1.5 years after graduation and doing work in which leadership competences are vital, it is a serious failure in the perception of that fact.

Study limitations

About $25 \%$ of the graduates from non-engineering fields at TUT also participated in the study and it was not possible to filter out their responses in the database because the web-based survey was carried out anonymously.

\section{REFERENCES}

[1] A.A. Bakar, C-Y. Ting, "Soft skills recommendation systems for IT jobs - A Bayesian network approach", IEEE Data Mining and Optimization (DMO), $20113^{\text {rd }}$ Conference on, pp. 82-87.

[2] Q. Brown, F. Lee \& S. Alejandre, "Emphasizing soft skills and team development in an educational digital game design course", Modern Applied Science, vol. 5, no. 2; April 2011

[3] D. Beard, D. Schwieger, K. Surendran, "Incorporating soft skills into accounting and MIS curricula", Special Interest Group on Computer Personnel Research Annual Conference - SIGCPR, pp. 179-185, 2007.

[4] L. Carter, "Ideas for adding soft skills education to service learning and capstone courses for computer science students", Proceedings SIGCSE ' 11 Proceedings of the $42^{\text {nd }}$ ACM technical symposium on Computer science education, 2011, pp. 517-522.

[5] D.J. Bayless \& T.R. Robe, "Leadership education for engineering students", Conference on Frontiers in Education - FECS, pp. 1-6, 2010.

[6] P. Shakespeare, P. Keleher \& L. Moxham, "Soft Skills, Hard Skills and Practice Identity", The Open University's Centres for Excellence in Teaching and Learning, 2007.

[7] R. Burns, L. Pollock, T. Harvey, "Integrating hard and soft skills: software engineers serving middle school teachers" Proceedings SIGCSE' 12 Proceedings of the 43rd ACM technical symposium on Computer Science Education, 2012, pp. 209-214.
[8] C. Del Vitto, "Cross-Cultural "Soft Skills" and the Global Engineer: Corporate Best Practices and Trainer Methodologies," Online Journal for Global Engineering Education, vol. 3, issue 1, pp. 1-9, 2008

[9] R. Dravid \& A. Duncan, "Engineering soft skills development to avoid hard knocks", Global Engineering Education Conference (EDUCON), IEEE, 2011.

[10] A. Dudman \& S.H. Wearne, "Professional Engineers' Needs for Managerial Skills and Expertise", Centre for Research in the Management of Projects University of Manchester Institute of Science \& Technology, 2003.

[11] T.L. Eng, "Teaching oral communication at MIT - The concept module", Education Technology and Computer (ICETC), 2nd International Conference, June 2010, pp. 541-545, 2010.

[12] G. Hillmer, "Social \& Soft Skills Training Concept in Engineering Education," Innovations 2007: World innovations in Engineering education and research, International Network for Engineering Education and Research, W. Aung, et al. (eds.), iNEER, Arlington, VA, 2007, Chap. 32, pp. 355-366.

[13] T.L. Lewis, N.J. Smith, F. Belanger \& K.V. Harrington, "Are Technical and Soft Skills Required? The Use of Structural Equation Modeling to Examine Factors Leading to Retention in the CS Major", Proceedings of the ICER'08, ACM Press, pp. 91-99, 2008.

[14] B. Manullang, S.M.M.S. Kons, "The integration of soft skill and hard skill in learning revolution", Education Technology and Computer (ICETC), $2^{\text {nd }}$ International Conference, pp. 436-439, 2010.

[15] A. Marks, \& D.M. Scholarios, "Choreographing a system: skill and employability in software work", Economic and Industrial Democracy, vol. 29 issue 1, pp. 96-124, 2008. http://dx.doi.org/10.1177/0143831X07085141

[16] V. Smith, "Review article: Enhancing employability: Human, cultural, and social capital in an era of turbulent unpredictability", Human Relations, vol. 63, 2, pp. 279-300, 2010. http://dx.doi.org/10.1177/0018726709353639

[17] M. Stuart \& E. Wallis, "Partnership Approaches to Learning: A Seven-country Study", European Journal of Industrial Relations, vol. 13, issue 3, pp. 301-321, 2007. http://dx.doi.org/ $\underline{10.1177 / 0959680107081743}$

[18] V. Saravanan, "Sustainable Employability Skills for Engineering Professionals", The Indian Review of World Literature in English, Vol. 5 No.II, July, 2009.

[19] B. Penzenstadler, G. Haller, T. Schlosser, G. Frenzel, "Soft skills required: A practical approach for empowering soft skills in the engineering world", Techniche Universität München, Workshop CIRCUS RE'09, 2009.

[20] M.A. Forero Rueda \& M.D. Gilchrist, "Student Competitions Enhance the Learning of Nontechnical Skills for Large Cohorts of Freshman Engineers", Transforming Engineering Education: Creating Interdisciplinary Skills for Complex Global Environments, 2010 IEEE, pp. 1-5, 2010.

[21] D.H. Stevenson \& J.A. Starkweather, "PM critical competency index: IT execs prefer soft skills", International Journal of Project Management, Oct 2010, vol. 28, issue 7, pp. 663-671. http://dx.doi.org/10.1016/j.ijproman.2009.11.008

[22] H.K. Mammi, \& N. Ithnin, (2012). "Competecy based education (CBE) for IT security: Towards bridging the gap", International Journal of Engineering Pedagogy (iJEP), vol 2, no 4 (2012), pp. 24-26.

[23] D. G. Dowling, "Designing a Competency Based Program to Facilitate the Progression of Experienced Engineering Technologists to Professional Engineer Status", European Journal of Engineering Education, vol. 31, 1, pp. 95-107, 2006. http://dx.doi.org/10.1080/03043790500429542

[24] C.C. Lundberg, "Planning the Executive Development Program," California Management Review; Fall 1972, vol. 15, issue 1, pp.110.

[25] G. Hamel \& C.K. Prahalad, "The Core Competence of the Corporation", Harvard Businees Review, 1990.

[26] L.M. Spencer, \& S.M. Spencer, "Competence at Work: Models for superior performance”, New York: John Wiley \& Sons, 1993. 
[27] R.A. Roe (2002). What makes a competent psychologist? European Psychologist, 7, pp. 192-202. http://dx.doi.org/10.1027/ /1016-9040.7.3.192

[28] R.A. Roe, "Competenties - Een sleutel tot integratie in theorie en praktijk van de A\&O-psychologie". [Competences - A key towards integration in theory and practice in W\&O Psychology], Gedrag \& Organisatie, vol. 15, issue 4, pp. 203-224, 2002.

[29] M. Depolo, L. Munduate, J.-M. Peiró, R.A. Roe, B. Sverko, M. Vartiainen, "EuroPsy and the advanced certificate in W\&O Psychology", Report of EAWOP Task Force on the Future Professional Qualifications of European W\&O Psychologists, 2008.

[30] D. Bartram \& R.A. Roe, "Definition and Assessment of Competences in the Context of the European Diploma in Psychology", European Psychologist, vol. 10, issue 2, pp. 93-102, 2005. http://dx.doi.org/10.1027/1016-9040.10.2.93

[31] G. Boak, "Developing managerial competences: The management learning contract approach", London: Pitman, 1991.

[32] J. Burgoyne, "Competency Based Approaches to Management Development", Lancaster: Centre for the Study of Management Learning, 1988.

[33] R. Eamets, K. Krillo, A. Themas, "Eesti kõrgkoolide 2009. aasta vilistlaste uuring", [Estonian universities graduates study - alumni of 2009], Tartu, 2011.

\section{AUTHORS}

V. Parts is Research Fellow at the Department of Industrial Psychology at Tallinn University of Technology, Ehitajate tee 5, 19086, Tallinn, Estonia (e-mail: velli.parts@enop.ee).

M. Teichmann is Professor and Head of the Department of Industrial Psychology at Tallinn University of Technology, Ehitajate tee 5, Tallinn, 19086, Estonia (email:mare@pekonsult.ee).

T. Rüütmann is Associate Professor, Head of Estonian Centre for Engineering Pedagogy at Tallinn University of Technology, Ehitajate tee 5, 19086, Tallinn, Estonia (email: tiia.ruutmann@ttu.ee), Member of IGIP EC.

Received 30 November 2012. Published as resubmitted by the authors 18 March 2013 